\title{
1-(4-Nitrophenyl)-1H-1,2,3-Triazole-4-carbaldehyde: Scalable Synthesis and Its Use in the Preparation of 1-Alkyl-4-Formyl-1,2,3-triazoles
}

\author{
Tomas Opsomer ${ }^{1}$ (D), Kaat Valkeneers ${ }^{1}$, Ana Ratković ${ }^{2}$ and Wim Dehaen ${ }^{1, *(D)}$ \\ 1 Molecular Design and Synthesis, Department of Chemistry, KU Leuven, Celestijnenlaan 200F, 3001 Leuven, \\ Belgium; tomasopsomer@hotmail.com (T.O.); kaat_valkeneers@hotmail.com (K.V.) \\ 2 Department of Organic Chemistry, Faculty of Chemical Engineering and Technology, University of Zagreb, \\ Marulićev trg 19, 10000 Zagreb, Croatia; ana.ratkovic30@gmail.com \\ * Correspondence: wim.dehaen@kuleuven.be
}

Citation: Opsomer, T.; Valkeneers, K.; Ratković, A.; Dehaen, $\mathrm{W}$.

1-(4-Nitrophenyl)-1H-1,2,3-Triazole-4carbaldehyde: Scalable Synthesis and Its Use in the Preparation of 1-Alkyl-4-Formyl-1,2,3-triazoles. Organics 2021, 2, 404-414. https:// doi.org/10.3390/org2040024

Academic Editor: Luísa M. Ferreira

Received: 27 September 2021

Accepted: 16 November 2021

Published: 6 December 2021

Publisher's Note: MDPI stays neutral with regard to jurisdictional claims in published maps and institutional affiliations.

Copyright: () 2021 by the authors. Licensee MDPI, Basel, Switzerland. This article is an open access article distributed under the terms and conditions of the Creative Commons Attribution (CC BY) license (https:// creativecommons.org/licenses/by/ $4.0 /)$.

\begin{abstract}
Triazole-4-carbaldehydes are useful synthetic intermediates which may play an important role in the discovery of novel applications of the 1,2,3-triazole moiety. In this work, a one-step multigram scale synthesis of 4-formyl-1-(4-nitrophenyl)-1H-1,2,3-triazole (FNPT) as a preferred reagent for the synthesis of 1-alkyl-4-formyltriazoles is described, making use of the commercially available 3-dimethylaminoacrolein and 4-nitrophenyl azide. Next, the earlier reported reaction of FNPT with alkylamines is further explored, and for hexylamine, the one-pot sequential cycloaddition and Cornforth rearrangement is demonstrated. In addition, a useful protocol for the in situ diazotization of 4-nitroaniline is provided. This facilitated the complete hydrolysis of rearranged 4-iminomethyl-1,2,3-triazoles and allowed for the recycling of 4-nitrophenyl azide.
\end{abstract}

Keywords: 1,2,3-triazole; aldehyde; cycloaddition; enamine; Cornforth; rearrangement; amines; metal-free

\section{Introduction}

4-Formyl-1,2,3-triazoles, also known as 1,2,3-triazole-4-carbaldehydes, are widely present in the literature, mainly due to the synthetic versatility of the formyl group [1-7]. In the field of medicinal chemistry [7], triazole-4-carbaldehydes have been prepared as intermediates in the synthesis of anticancer [8-10], antifungal [11,12], antituberculosis [13-15], anti-inflammatory [10,16], antidiabetic [17], and even bioimaging agents [18]. Furthermore, imine derivatives have been synthesized as interesting ligands in coordination chemistry [19-21]. 1-Substituted 4-formyl-1,2,3-triazoles are commonly prepared via a two-step synthesis involving the copper-catalyzed azide-alkyne cycloaddition reaction with azides and propargyl alcohol [2,9-13,15-18,22] or acetal-protected propargyl aldehydes $[3,5,6,8,23,24]$, followed by oxidation or hydrolysis, respectively. These methods are clever alternatives for the cycloaddition between azides and the low boiling propynal, which is inconvenient to handle. Commonly used oxidants include manganese dioxide [11,12,18], 2-iodoxybenzoic acid (IBX) [13,15,17], and hexavalent chromium compounds $[2,9,10,16,22]$. Despite their wide application, a few drawbacks of the coppercatalyzed click reactions can be named. Firstly, the scope is limited to compounds that tolerate strong oxidative or acidic conditions. Secondly, the use of the copper catalyst and the need for different azido compounds for the synthesis of analogues can be seen as unfavorable features.

Throughout the past decade, methods have been reported that circumvent the isolation of different azides, strong oxidative or acidic conditions, or the use of a metal catalyst. Fletcher et al. showed that the substitution of alkyl bromides with sodium azide was feasible under 'click' conditions in a $t \mathrm{BuOH} /$ water mixture [24], and the alkyl azides were reacted in situ with propargylaldehyde diethyl acetal. Interestingly, the complete 
hydrolysis of the acetal function on the resulting triazoles was observed at $70{ }^{\circ} \mathrm{C}$ without the use of acid [24,25]. Yao et al. demonstrated the oxidative cycloaddition of benzyl azide to acrolein under copper catalysis in the presence of Hünig's base and oxygen at $80{ }^{\circ} \mathrm{C}$ [26]. A copper-free three-step method was exemplified by Li, Wang et al. who performed the regioselective cycloaddition of phenyl azide to methyl 3-methoxyacrylate, followed by a reduction and oxidation using DIBAL and PCC, respectively [27]. Recently, Gao et al. disclosed a metal- and oxidant-free approach starting from $\alpha$-bromoacroleins and azides [28]. This eliminative cycloaddition was carried out under mild conditions and had a wide substrate scope. However, the bromoacroleins are poorly available and need to be synthesized from acroleins and bromine at low temperature.

In 1989, L'abbé et al. studied the thermal rearrangement of 5-amino-4-iminomethyl-1aryl-1,2,3-triazoles [29]. Instead of Dimroth rearrangement towards 5-anilino- $\mathrm{NH}$-triazoles, the formation of 4-amidino-1,2,3-triazoles was observed as a result of the triazole-diazoimine equilibrium. This ring-degenerate rearrangement can be classified as a type of Cornforth rearrangement [30] and was recently applied by our group for the synthesis of bitriazoles from $\alpha$-ketotriazoles [31]. L'abbé conceived the triazole-diazoimine equilibrium as a tool for the replacement of aryl by alkyl substituents in 1-substituted 4-formyl-1,2,3triazoles 1 (Scheme 1) [32,33]. The synthesis of 1-alkyl-1,2,3-triazoles 7 was carried out in three separate steps, namely imine formation, Cornforth rearrangement, and hydrolysis, and was introduced as a useful pathway to avoid the use of low-boiling explosive alkyl azides [20,21]. In addition, this method is particularly interesting when the primary amine is more available than its corresponding azide.

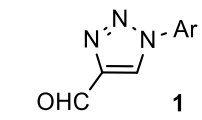

$\mathrm{H}_{2} \mathrm{O}, \mathrm{H}^{+} \| \mathrm{AlkNH}_{2} 2$

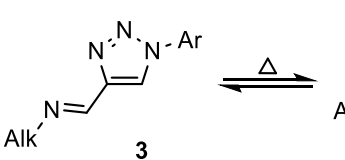

3
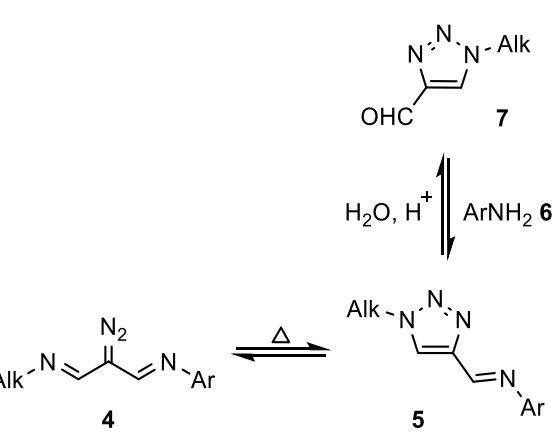

Scheme 1. Reaction of 1-aryl-4-formyl-1,2,3-triazoles with alkylamines, involving ring-degenerate Cornforth rearrangement and hydrolysis of the resulting 4-iminomethyl-1,2,3-triazoles.

As described by L'abbé, the equilibrium of the Cornforth rearrangement is shifted toward the triazole with the most electron-deficient substituent on the imine nitrogen. Fletcher et al., who further studied this rearrangement in 2018, observed the same trend [34]. The condensation of different 1-aryl-4-formyl-1,2,3-triazoles 1 and anilines gave dynamic mixtures with up to six different triazole compounds. In contrast, reactions with aniline and 4-formyl-1-(4-nitrophenyl)triazole 1a (FNPT; Scheme 2) only gave rearranged products. As a consequence, FNPT 1a was put forward as a preferred reagent for the synthesis of 1-subsituted 4-formyltriazoles and can be seen as a safe alternative for diazomalonaldehyde $[14,35]$. Onoda et al. applied this strategy for the preparation of 1-alkyl-4-formyltriazoles 7 that could be used for the $N$-terminal modification of proteins [1]. Interestingly, a procedure was developed starting from FNPT 1a and primary amines that allowed for protein modification in excellent conversions without isolating the targeted aldehydes 7. Following our ongoing interest in the synthesis of 1,2,3-triazoles [36-38], we recognized the potential of this approach for the metal-free synthesis of 1-alkyl-4-formyl-1,2,3-triazoles 7. However, to the best of our knowledge, a metal-free and straightforward synthesis of FNPT 1a on a preparative scale was still lacking. 


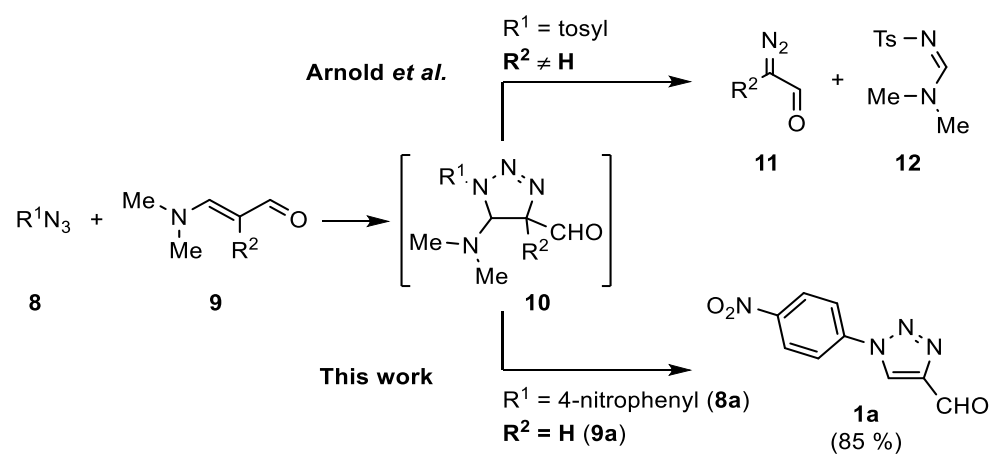

Scheme 2. Synthesis of $\alpha$-diazoaldehydes $\mathbf{1 1}$ described by Arnold et al. and the cycloaddition of 3-dimethylaminoacrolein 9a and 4-nitrophenyl azide 8a described in this work.

In 1970, Arnold et al. reported the synthesis of $\alpha$-diazoaldehydes 11 from 2-alkyl-3-dimethylaminoacroleins $9\left(\mathrm{R}^{2} \neq \mathrm{H}\right)$ and tosyl azide (Scheme 2) [39]. This transformation involves a retro 1,3-dipolar cycloaddition of triazoline 10. When using 2-unsubstituted 3-dimethylaminoacroleins $9\left(\mathrm{R}^{2}=\mathrm{H}\right)$, however, only a trace amount of diazoacetalde hyde $\mathbf{1 1}$ was obtained. To the best of our knowledge, the reaction of aminoacroleins with azides was not further studied. As enamines are among the best known starting materials for the synthesis of 1,2,3-triazoles [36,37,40,41], it is rather surprising that the commercially available and rather inexpensive 3-dimethylaminoacrolein $9 \mathbf{a}$ somehow remained unnoticed as a possible reagent for the synthesis of 4-formyl-1,2,3-triazoles.

\section{Results and Discussions}

The first aim of this work was to develop a protocol for the metal-free synthesis of FNPT 1a on a preparative scale (Scheme 3). The reaction between 3-dimethylaminoacrolein 9a and 4-nitrophenyl azide 8a was first evaluated on a submillimolar scale. To our delight, high yields above $80 \%$ of the desired 4-formyltriazole 1 a were obtained from reactions in aprotic polar solvents (DMF, DMSO, 1,4-dioxane, $\mathrm{MeCN}$ ) at $50{ }^{\circ} \mathrm{C}$. Three days were needed in order to reach the desired conversion of the reagents in an equimolar ratio. In isopropanol, the cycloaddition was significantly slower, and protic solvents were therefore not further studied. DMSO and DMF were selected as the optimal solvents, affording reproducible yields of $86-88 \%$. Our aim was to avoid chromatographic purification. Therefore, in initial experiments, the reaction mixtures were diluted with ethyl acetate, washed with water, and concentrated. The sufficiently pure product was obtained after precipitation from pentane. Unfortunately, this protocol failed for reactions on a gram scale in several ways. The yield decreased significantly, and a large amount of ethyl acetate was required in order to keep the product in solution. More importantly, the isolated product was less pure, as observed via ${ }^{1} \mathrm{H}$ NMR analysis. Therefore, the conditions were re-evaluated on gram scale. An excess of the water soluble acrolein 9a (1.3 equiv) was used in order to attain full conversion. When using 1,4-dioxane as the reaction solvent, precipitation of the product by pouring the mixture in aqueous $\mathrm{HCl}$ could afford the crude product in circa $90 \%$ yield. Nevertheless, the desired purity was still not acquired. The reaction was also carried out under a constant nitrogen flow to remove the released dimethylamine. However, this had no influence on the reaction outcome. Additionally, attempts to grow crystals of the product failed. Eventually, it was found that the use of 1.3 equivalents of 4-nitrophenyl azide 8a gave a cleaner reaction mixture. The precipitation of the product $1 \mathbf{a}$ by adding equal portions of aqueous $\mathrm{HCl}$ and diethyl ether, filtration, and washing of the solid with water and diethyl ether gave a pure solid in an acceptable yield of $85 \%$ on gram scale. It should be noted that when washing the isolated solid with pentane, the resulting powder was statically charged and therefore difficult to handle. Finally, the procedure was repeated starting from $50 \mathrm{mmol}$ of 3-dimethylaminoacrolein $\mathbf{9 a}$, and the pure triazole $1 \mathbf{a}$ was isolated in a slightly lower but acceptable yield of $79 \%$ after filtration. It was assumed that a part of the product 
was taken up in the water layer as the hydrate, which was substantiated by the ${ }^{1} \mathrm{H}$ NMR analysis of the acquired solid before the evaporation of the residual solvents under vacuo (see Supplementary Materials, Figure S1). Nevertheless, we were pleased to see that further chromatographic purification of the ether phase of the filtrate gave another $0.94 \mathrm{~g} \mathrm{(9 \% )} \mathrm{of}$ the triazole $1 \mathrm{a}$ and allowed for the complete recovery of the excess of 4-nitrophenyl azide.

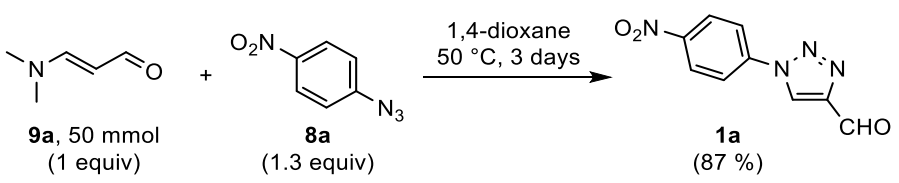

Scheme 3. Synthesis of 4-formyl-1-(4-nitrophenyl)triazole (FNPT) 1a from 3-dimethylaminoacrolein 9a and 4-nitrophenyl azide $8 \mathbf{a}$.

Although the cycloaddition of 4-nitrophenyl azide 8a to 3-dimethylaminoacrolein 9a was successful, the scope of azides was not further explored in this work. A preliminary experiment with phenyl azide showed that the cycloaddition was slow, even at $80{ }^{\circ} \mathrm{C}$. Furthermore, increasing the temperature resulted in a crude product with an inferior purity profile compared to reactions at $50{ }^{\circ} \mathrm{C}$. Based on this observation, it is expected that azides with electron-deficient aryl groups will be the most suitable substrates for the synthesis of 1-aryl-4-formyl-1,2,3-triazoles from 3-dimethylaminoacrolein.

With a metal-free protocol for the multigram scale preparation of FNPT 1a in hand, we wanted to further explore the previously reported reaction with primary amines 2 [1,20,32-34], i.e., imine formation, Cornforth rearrangement, and hydrolysis, in a single step (Table 1). The study was initiated with hexylamine. Cornforth rearrangement of the in situ generated 4-(hexylimino)methyl-1,2,3-triazole occurred efficiently at $80^{\circ} \mathrm{C}$ in solvents such as isopropanol $(\mathrm{PrOH}), 1,4$-dioxane, and water. Full conversion toward the rearranged products was also achieved at $50{ }^{\circ} \mathrm{C}$, although longer reaction times were required, i.e., in the order of $24 \mathrm{~h}$ in $\mathrm{iPrOH}$ and $48 \mathrm{~h}$ in water. It is important to note that when water was used, a fine suspension of triazole $\mathbf{1 a}$ and the solubility of the amine in water were crucial for the reaction to run smoothly. Reactions with hexylamine were analyzed by means of ${ }^{1} \mathrm{H}$ NMR after concentrating the crude mixtures under vacuo. For each solvent, a mixture of rearranged 4-iminomethyltriazoles and the desired 1-alkyl-4-formyltriazole 7a was obtained, with the latter as the major product. Since Onoda et al. observed the complete hydrolysis of rearranged iminomethyltriazoles after $30 \mathrm{~min}$ at $99{ }^{\circ} \mathrm{C}$ in DMSO- $d_{6}$ [1], one could assume that the target aldehyde may partly recondense with the liberated 4-nitroaniline 6a when the mixtures were concentrated. Unfortunately, the complete removal of nitroaniline by means of acidic extractions with ethyl acetate or diethylether was unsuccessful and led to significant losses of product. Interestingly, L'abbé et al. reported that such imines hydrolyze during chromatographic work-up using silica [42]. For those reasons, reactions mixtures with $i \mathrm{PrOH}$ or dioxane were concentrated and immediately purified via column chromatography. To our delight, the pure triazole 7 a was isolated in a $94 \%$ yield for both reaction solvents. 
Table 1. Synthesis of 1-alkyl-4-formyl-1,2,3-triazoles 7a-h from primary amines 2 and FNPT 1a: Reaction conditions and yields.

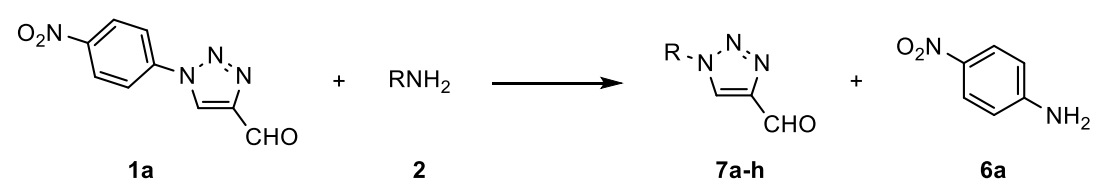

1a

2

7a-h 6a

\begin{tabular}{|c|c|c|c|c|c|c|c|c|}
\hline Entry & Amine 2 & $2(\mathrm{mmol})$ & $\begin{array}{c}1 \mathrm{a} \\
(\mathrm{mmol})\end{array}$ & Solvent & $\begin{array}{l}\text { Reaction } \\
\text { Time (h) }\end{array}$ & $\mathrm{T}\left({ }^{\circ} \mathrm{C}\right)$ & Product 7 & Yield (\%) \\
\hline $\mathrm{a}$ & $\mathrm{NH}_{3}$ & 0.55 & 0.5 & $\begin{array}{l}i \mathrm{PrOH} \\
(1 \mathrm{~mL})\end{array}$ & 15 & 80 & & 94 \\
\hline $\mathrm{b}$ & & 3 & 2.5 & $\begin{array}{l}i \mathrm{PrOH} \\
(5 \mathrm{~mL})\end{array}$ & 15 & 80 & & 82 \\
\hline c & & 0.55 & 0.5 & $\begin{array}{l}i \mathrm{PrOH} \\
(1 \mathrm{~mL})\end{array}$ & 15 & 80 & & 95 \\
\hline $\mathrm{d}$ & & 0.55 & 0.5 & $\begin{array}{l}i \operatorname{PrOH} \\
(1 \mathrm{~mL})\end{array}$ & 15 & 80 & & 93 \\
\hline $\mathrm{e}$ & & 0.55 & 0.5 & $\begin{array}{c}1,4- \\
\text { Dioxane } \\
(1 \mathrm{~mL})\end{array}$ & 18 & 70 & & 65 \\
\hline $\mathrm{f}$ & ${ }_{\mathrm{OMe}}^{\mathrm{MeO}} \mathrm{NH}_{2}$ & 0.55 & 0.5 & $\begin{array}{l}i \operatorname{PrOH} \\
(1 \mathrm{~mL})\end{array}$ & 15 & 80 & & 93 \\
\hline $\mathrm{g}$ & & 0.55 & 0.5 & $\begin{array}{l}i \mathrm{PrOH} \\
(1 \mathrm{~mL})\end{array}$ & 15 & 80 & 0 & 41 \\
\hline $\mathrm{g}$ & $"$ & 0.55 & 0.5 & $\begin{array}{c}1,4- \\
\text { Dioxane } \\
(1 \mathrm{~mL})\end{array}$ & 15 & 80 & $"$ & 45 \\
\hline $\mathrm{h}$ & & 0.25 & 0.83 & $\begin{array}{c}i \mathrm{PrOH} \\
(0.5 \mathrm{~mL}) \\
\mathrm{H}_{2} \mathrm{O} \\
(1.5 \mathrm{~mL})\end{array}$ & 17 & 80 & & 90 \\
\hline
\end{tabular}

Next, other amines were evaluated (Table 1). Reactions with benzylamine, as well as the acid-sensitive allylamine and aminoacetaldehyde dimethyl acetal were successful and gave excellent yields of the respective formyltriazoles 7c, 7d, and 7f. 4-Formyl-1-methyl1,2,3-triazole $7 \mathbf{b}$ was synthesized in $82 \%$ by using a commercial solution of methylamine in isopropanol. Due to its volatility under vacuum at elevated temperatures, sublimation in a Kugelrohr or cold finger equipment could be used to crystallize the product. The use of tert-butyl glycinate resulted in lower but comparable yields of $\mathbf{7 g}$ in both $i \mathrm{PrOH}$ (41\%) and dioxane (46\%). 1-Propargyl-4-formyltriazole 7e, which is currently not accessible by other means, was successfully prepared in a $65 \%$ yield from propargylamine in dioxane at $70{ }^{\circ} \mathrm{C}$. Interestingly, tristriazole $7 \mathrm{~h}$ could be synthesized in a $90 \%$ yield from tris(2-aminoethyl)amine by performing the reaction in a 1:3 mixture of isopropanol and water.

While suitable conditions were found for reactions with alkylamines, the reaction with aniline in 1,4-dioxane at $80^{\circ} \mathrm{C}$ was slow. Moreover, hydrolysis of the resulting imine on silica failed, which hampered the isolation of 4-formyl-1-phenyl-1,2,3-triazole. We therefore believe that the protocol of Fletcher et al. [34], among other synthetic methods, should be recommended for the preparation of 1-aryl-4-formyltriazoles. 
The reaction with hexylamine in isopropanol was then carried out on a multigram scale. Unfavorably, the hydrolysis of rearranged 4-iminomethyl-1,2,3-triazoles on silica was less efficient in this case, making the purification via column chromatography inconvenient. This issue could be largely resolved by removing a part of the nitroaniline 6a by means of an acidic extraction prior to the chromatographic purification. The product 7 a was eventually obtained in a yield of $73 \%$. To further demonstrate the utility of this chemistry, 4-formyl-1-hexyl-1,2,3-triazole 7a was also successfully prepared via a two-step one-pot reaction, starting from 3-dimethylaminoacrolein 9a, 4-nitrophenyl azide 8a and hexylamine (Scheme 4).

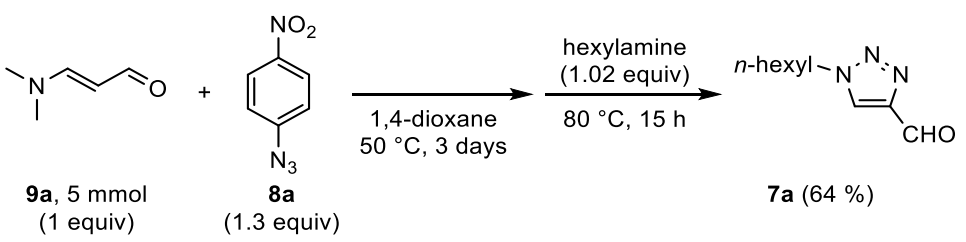

Scheme 4. One-pot synthesis of 4-formyl-1-hexyl-1,2,3-triazole 7a from 3-dimethylaminoacrolein 9a, 4-nitrophenyl azide 8a, and hexylamine.

In a later stage of this work, we envisioned that the reactions in isopropanol or water could be part of a protocol for the direct regeneration of 4-nitrophenyl azide 8a. Our group earlier demonstrated the in situ diazotization of 4-nitroaniline $6 \mathbf{a}$ after a three-component triazole synthesis from ketones, primary amines, and 4-nitrophenyl azide [43]. Although such a procedure would not be applicable to the acid-sensitive substrates, it could possibly enhance the hydrolysis of the rearranged iminomethyltriazoles, which would largely reduce the amount of solvent required for the chromatographic purification. After the reaction of FNPT 1a and hexylamine in isopropanol, 4-nitroaniline $6 \mathbf{a}$ was diazotized via the addition of isopropanol, aqueous $\mathrm{HCl}$, and sodium nitrate. We were pleased to see that the imines were fully hydrolyzed under the diazotization conditions. In this way, the pure 4-formyl-1-hexyl-1,2,3-triazole 7a could be isolated in a 96\% yield via a simple extraction on the scale of $0.5 \mathrm{mmol}$. For the gram scale synthesis, however, further purification of the crude product was required. While the formyltriazole 7 a was isolated in a yield of $70 \%$, nitrophenyl azide $8 \mathbf{a}$ was regenerated in $80 \%$ yield.

\section{Conclusions}

The commercial 3-dimethylaminoacrolein 9a was introduced as a starting material for the metal-free synthesis of 4-formyl-1,2,3-triazoles. First, a method was devised for the multigram scale cycloaddition of 3-dimethylaminoacrolein 9a with 4-nitrophenyl azide 8a, providing 1-(4-nitrophenyl)-1H-1,2,3-triazole-4-carbaldehyde 1a (FNPT) after a simple filtration. Next, this triazole was reacted with primary amines 2 for the synthesis of 1-alkyl-4-formyl-1,2,3-triazoles 7 in a single step. For small scale reactions, column chromatography facilitated the hydrolysis of residual 4-iminomethyl-1,2,3-triazoles, and pure formyltriazoles $7 \mathbf{a}-\mathbf{h}$ were readily obtained in moderate to excellent yields. For hexylamine, the two-step synthesis was also demonstrated in a one-pot fashion. Despite the favorable results, the hydrolysis of the imines on silica was often a slow process that resulted in a solvent-demanding purification procedure. Consequently, a protocol was exemplified for the in situ diazotization of 4-nitroaniline $\mathbf{6 a}$, which allowed for the recovery of 4-nitrophenyl azide 8a in a good yield. This facilitated the complete hydrolysis of the iminomethyltriazoles, but the requirement for column chromatography could still not be avoided when applying this protocol to a gram scale synthesis. Overall, the important advantages of this two-step synthesis are the applicability to acid-sensitive substrates and the fact that the use of volatile and hazardous alkyl azides can be circumvented. We therefore believe that the protocols presented herein can be very useful for the preparation of synthetic intermediates, e.g., in the search for novel lead compounds, which require 
rapid access to a variety of analogs. So far, the protocols reported herein have already been successfully applied for the preparation of 1,2,3-triazole di-heterostilbenes [44].

\section{Materials and Methods}

All chemicals were purchased from Acros Organics, Merck, Fluorochem, J\&K Scientific, and TCI Europe, and used as received. 4-Nitrophenyl azide 8a was prepared on multigram scale according to a procedure previously reported in the literature [45]. Thin layer chromatography (TLC) was performed using silica gel with fluorescent indicator $254 \mathrm{~nm}$ precoated on aluminum sheets (Merck). For column chromatography, 70-230 mesh silica 60 (Acros) was used as the stationary phase. ${ }^{1} \mathrm{H}$ and ${ }^{13} \mathrm{C}$ NMR spectra were recorded on a Bruker Avance 300, Bruker Avance III HD 400, or a Bruker Avance II 600 spectrometer. Chemical shifts $(\delta)$ were reported in parts per million $(\mathrm{ppm})$ referenced to tetramethylsilane $(0.00 \mathrm{ppm})$ as an internal standard for samples in $\mathrm{CDCl}_{3}$, or to the solvent signal for samples in DMSO- $d_{6}(2.50 \mathrm{ppm}) .{ }^{13} \mathrm{C}$ NMR spectra were referenced to the respective solvent signals $\left(\mathrm{CDCl}_{3}, 77.16 \mathrm{ppm} ; \mathrm{DMSO}-d_{6}, 39.52 \mathrm{ppm}\right)$. High-resolution mass spectra were acquired on a quadrupole orthogonal acceleration time-of-flight mass spectrometer (Synapt G2 HDMS, Waters, Milford, MA, USA). Samples were infused at $3 \mu \mathrm{L} / \mathrm{min}$ and spectra were obtained in positive ionization mode with a resolution of 15,000 (FWHM) using leucine enkephalin as lock mass. Melting points (not corrected) were determined using a Reichert Thermovar apparatus.

1-(4-Nitrophenyl)-1H-1,2,3-triazole-4-carbaldehyde (FNPT; 1a). To a screw-capped $40 \mathrm{~mL}$ reaction tube equipped with a magnetic stirring bar were added 4-nitrophenyl azide $8 \mathbf{a}(65 \mathrm{mmol}, 10.7 \mathrm{~g})$, 3-dimethylaminoacrolein $9 \mathrm{a}(50 \mathrm{mmol}, 5 \mathrm{~g})$, and 1,4-dioxane ( $25 \mathrm{~mL})$. The mixture was stirred at $50{ }^{\circ} \mathrm{C}$ for $72 \mathrm{~h}$, after which the solvent was reduced by half under reduced pressure. The reaction mixture was then diluted with $1 \mathrm{M} \mathrm{HCl}$ (aq., $50 \mathrm{~mL}$ ) and $\mathrm{Et}_{2} \mathrm{O}(50 \mathrm{~mL})$, and the mixture was shaken in a separation funnel until a white suspension was obtained. The precipitate was filtered of and washed with water $(3 \times 50 \mathrm{~mL})$ and $\mathrm{Et}_{2} \mathrm{O}(4 \times 50 \mathrm{~mL})$. The solid was further dried in vacuo in order to obtain $8.58 \mathrm{~g}(79 \%)$ of the pure triazole 1a. The filtrate was transferred to a separation funnel and the organic layer was washed with $1 \mathrm{M} \mathrm{HCl}$ (aq., $120 \mathrm{~mL}$ ), saturated $\mathrm{NaHCO}_{3}$ (aq., $100 \mathrm{~mL}$ ), and brine $(100 \mathrm{~mL})$. The ether phase was then dried over $\mathrm{MgSO}_{4}$, filtered, and concentrated. The residue was purified via column chromatography using a petroleum-ether/DCM gradient (1:1) to recover the pure unreacted 4-nitrophenyl azide $8 \mathrm{a}(2.6 \mathrm{~g})$, followed by a $\mathrm{DCM} / \mathrm{MeOH}$ gradient (1:0-19:1) to collect another $0.94 \mathrm{~g}(9 \%)$ of triazole 1a. Off-white solid; yield: $9.52 \mathrm{~g}(87 \%) ; \mathrm{mp} 173-174{ }^{\circ} \mathrm{C} ;{ }^{1} \mathrm{H}$ NMR $\left(300 \mathrm{MHz}\right.$, DMSO- $\left.d_{6}\right) \delta 10.12(\mathrm{~s}, 1 \mathrm{H})$, $9.75(\mathrm{~s}, 1 \mathrm{H}), 8.45(\mathrm{~d}, J=9.1 \mathrm{~Hz}, 2 \mathrm{H}), 8.28(\mathrm{~d}, J=9.1 \mathrm{~Hz}, 2 \mathrm{H}) ;{ }^{13} \mathrm{C}$ NMR $(75 \mathrm{MHz}, \mathrm{DMSO})$ $\delta 184.9,147.8,147.3,140.2,126.8,125.5,121.4$. NMR data was in accordance with the previously reported data for this compound [1].

General procedure for the synthesis of 1-alkyl-1H-1,2,3-triazole-4-carbaldehydes. 4-Formyl-1-(4-nitrophenyl)-1,2,3-triazole (FNPT) 1 a $(0.5 \mathrm{mmol})$, primary amine $(0.55 \mathrm{mmol})$, water $(45 \mu \mathrm{L})$, and $\mathrm{PrOH}$ (or 1,4-dioxane) $(1 \mathrm{~mL})$ were added to a screw-capped reaction tube equipped with a magnetic stirring bar. The reaction mixture was stirred for $15 \mathrm{~h}$ at $80^{\circ} \mathrm{C}$, unless stated otherwise. Next, the reaction mixture was concentrated and directly purified via column chromatography.

1-Hexyl-1H-1,2,3-triazole-4-carbaldehyde (7a). Prepared according to the general procedure for the synthesis of 1-alkyl-1H-1,2,3-triazole-4-carbaldehydes; hexylamine $(0.55 \mathrm{mmol}, 56 \mathrm{mg}), i \mathrm{PrOH}$ as the reaction solvent. Purified via column chromatography using DCM as the eluent to remove 4-nitroaniline, followed by a DCM/EtOAc gradient (1:0 - 19:1). Clear yellowish oil that solidified over time; yield: $85 \mathrm{mg}(94 \%)$; $\mathrm{mp}$ $31-33{ }^{\circ} \mathrm{C} ;{ }^{1} \mathrm{H}$ NMR $\left(400 \mathrm{MHz}, \mathrm{CDCl}_{3}\right) \delta 10.14(\mathrm{~s}, 1 \mathrm{H}), 8.15(\mathrm{~s}, 1 \mathrm{H}), 4.45(\mathrm{t}, J=7.2 \mathrm{~Hz}, 2 \mathrm{H})$, 2.09-1.85 (m, 2H), 1.45-1.18 (m, 6H), 0.99-0.78 (m, 3H); $\left.{ }^{13} \mathrm{C} \mathrm{NMR} \mathrm{(151} \mathrm{MHz,} \mathrm{CDCl}_{3}\right) \delta$ $185.2,147.8,125.2,50.8,31.1,30.1,26.0,22.4,13.9$.

Procedure for the recovery of 4-nitrophenyl azide: FNPT 1a $(4.6 \mathrm{mmol}, 1 \mathrm{~g})$, hexylamine $(5.98 \mathrm{mmol}, 605 \mathrm{mg})$, water $(22 \mathrm{mmol}, 0.4 \mathrm{~mL})$, and $i \mathrm{PrOH}(10 \mathrm{~mL})$ were added to a 
screw-capped reaction tube equipped with a magnetic stirring bar. The reaction mixture was stirred for $25 \mathrm{~h}$ at $50{ }^{\circ} \mathrm{C}$. Next, the mixture was allowed to cool down and $4 \mathrm{M} \mathrm{HCl}$ (aq., $7 \mathrm{~mL})$ was added. At $0{ }^{\circ} \mathrm{C}$, a solution of $\mathrm{NaNO}_{2}(5.5 \mathrm{mmol}, 380 \mathrm{mg})$ in water $(1 \mathrm{~mL})$ was added dropwise while stirring, and the mixture was continued to stir for $30 \mathrm{~min}$ at $0{ }^{\circ} \mathrm{C}$. The aqueous solution was extracted with cold EtOAc $\left(20 \mathrm{~mL}, 0^{\circ} \mathrm{C}\right)$ and separated. To the aqueous layer, a solution of $\mathrm{NaN}_{3}(6.9 \mathrm{mmol}, 448 \mathrm{mg})$ in water $(1.5 \mathrm{~mL})$ was added dropwise at $0{ }^{\circ} \mathrm{C}$ and the mixture was subsequently stirred at room temperature for $3 \mathrm{~h}$. 4-Nitrophenyl azide was extracted with $\mathrm{Et}_{2} \mathrm{O}(20 \mathrm{~mL})$, and the organic layer was washed with $4 \mathrm{M} \mathrm{HCl}$ (aq., $29 \mathrm{~mL}$ ), saturated $\mathrm{NaHCO}_{3}$ (aq., $20 \mathrm{~mL}$ ), and brine $(10 \mathrm{~mL})$. The ether phase was then dried over $\mathrm{MgSO}_{4}$, filtered, and concentrated to afford 4-nitrophenyl azide 8a as a pure pale yellow solid; yield: $605 \mathrm{mg}(80 \%)$. The EtOAc layer was also washed with saturated $\mathrm{NaHCO}_{3}$ (aq., $20 \mathrm{~mL}$ ) and brine $(10 \mathrm{~mL})$, dried over $\mathrm{MgSO}_{4}$, filtered, and concentrated. Further purification via column chromatography using a DCM/EtOAc gradient (1:0—19:1) yielded the pure product 7a as a pale yellow semisolid; yield: $580 \mathrm{mg}$ (70\%).

One-pot procedure from 3-dimethylaminoacrolein: To a screw-capped $40 \mathrm{~mL}$ reaction tube equipped with a magnetic stirring bar were added 4-nitrophenyl azide 8a (6.5 mmol, $1.07 \mathrm{~g})$, 3-dimethylaminoacrolein 9a (5 mmol, $0.5 \mathrm{~g})$, and 1,4-dioxane (2.5 $\mathrm{mL})$. The mixture was stirred at $50{ }^{\circ} \mathrm{C}$ for $70 \mathrm{~h}$. Next, hexylamine $(5.1 \mathrm{mmol}, 516 \mathrm{mg})$, water $(450 \mu \mathrm{L})$, and 1,4-dioxane $(7.5 \mathrm{~mL})$ were added and the mixture was stirred for $15 \mathrm{~h}$ at $80{ }^{\circ} \mathrm{C}$. The reaction mixture was subsequently diluted with $\mathrm{Et}_{2} \mathrm{O}(100 \mathrm{~mL})$ and washed with $3 \mathrm{M} \mathrm{HCl}$ (aq., $2 \times 100 \mathrm{~mL}$ ), saturated $\mathrm{NaHCO}_{3}$ (aq., $50 \mathrm{~mL}$ ), and brine. The organic layer was dried over $\mathrm{MgSO}_{4}$, filtered, and concentrated. The crude product 7a was further purified via column chromatography using a petroleum-ether/DCM gradient (1:4-0:1) as the eluent to remove 4-nitroaniline, followed by a DCM/EtOAc gradient (1:0-4:1). Pale orange semisolid; yield: $581 \mathrm{mg}(64 \%)$.

1-Methyl-1H-1,2,3-triazole-4-carbaldehyde (7b). FNPT 1a (2.5 mmol, $545 \mathrm{mg})$, a solution of methylamine in $i \mathrm{PrOH}(2 \mathrm{M}, 1.5 \mathrm{~mL})$, and an additional amount of $i \mathrm{PrOH}$ $(3.5 \mathrm{~mL})$ were added to a screw-capped reaction tube equipped with a magnetic stirring bar. The reaction mixture was stirred for $15 \mathrm{~h}$ at $80^{\circ} \mathrm{C}$. Next, the crude product was coated on silica and directly purified via column chromatography using DCM as the eluent to remove 4-nitroaniline, followed by a DCM/MTBE gradient (1:0-1:1). Further purification was possible by sublimation in a Kugelrohr. White crystalline solid; yield: $229 \mathrm{mg}(82 \%)$; mp 112-114 ${ }^{\circ} \mathrm{C} ;{ }^{1} \mathrm{H}$ NMR $\left(300 \mathrm{MHz}, \mathrm{CDCl}_{3}\right) \delta 10.14(\mathrm{~s}, 1 \mathrm{H}), 8.15(\mathrm{~s}, 1 \mathrm{H}), 4.21(\mathrm{~s}, 3 \mathrm{H})$; ${ }^{13} \mathrm{C}$ NMR $\left(75 \mathrm{MHz}, \mathrm{CDCl}_{3}\right) \delta 185.1,148.1,126.3,37.2 ;{ }^{1} \mathrm{H}$ NMR (300 MHz, DMSO- $\left.d_{6}\right)$ $\delta 10.01(\mathrm{~s}, 1 \mathrm{H}), 8.81$ (s, 1H), 4.13 (s, 3H); ${ }^{13} \mathrm{C}$ NMR (151 MHz, DMSO) $\delta 185.0,147.0,128.8$, 36.7. NMR data was in accordance with the previously reported data for this compound [20].

1-Benzyl-1H-1,2,3-triazole-4-carbaldehyde (7c). Prepared according to the general procedure for the synthesis of 1-alkyl-1H-1,2,3-triazole-4-carbaldehydes; benzylamine ( $0.55 \mathrm{mmol}, 59 \mathrm{mg}), i \mathrm{PrOH}$ as the reaction solvent. Purified via column chromatography using a petroleum-ether/DCM gradient (1:4-0:1) as the eluent to remove 4-nitroaniline, followed by a DCM/EtOAc gradient (19:1-1:9). Clear oil with yellowish hue that solidified over time to give an off-white solid; yield: $89 \mathrm{mg}(95 \%) ; \mathrm{mp} 82-86{ }^{\circ} \mathrm{C} ;{ }^{1} \mathrm{H} \mathrm{NMR}(400 \mathrm{MHz}$, $\left.\mathrm{CDCl}_{3}\right) \delta 10.12(\mathrm{~s}, 1 \mathrm{H}), 8.02(\mathrm{~s}, 1 \mathrm{H}), 7.44-7.28(\mathrm{~m}, 5 \mathrm{H}), 5.60(\mathrm{~s}, 2 \mathrm{H}) ;{ }^{13} \mathrm{C} \mathrm{NMR}(101 \mathrm{MHz}$, $\left.\mathrm{CDCl}_{3}\right) \delta 185.2,148.1,133.5,129.5,129.4,128.5,125.3,54.7$. NMR data was in accordance with the previously reported data for this compound [24].

1-Allyl-1H-1,2,3-triazole-4-carbaldehyde (7d). Prepared according to the general procedure for the synthesis of 1-alkyl-1H-1,2,3-triazole-4-carbaldehydes; allylamine (0.55 mmol, $31 \mathrm{mg}$ ), $i \mathrm{PrOH}$ as the reaction solvent. Purified via column chromatography using a petroleum-ether/DCM gradient (1:4-0:1) as the eluent to remove 4-nitroaniline, followed by a DCM/EtOAc gradient (19:1-1:9). Clear oil with greenish hue; yield: $64 \mathrm{mg}(93 \%) ;{ }^{1} \mathrm{H}$ NMR (400 MHz, $\left.\mathrm{CDCl}_{3}\right) \delta 10.15(\mathrm{~s}, 1 \mathrm{H}), 8.16(\mathrm{~s}, 1 \mathrm{H}), 6.06$ (ddt, $\mathrm{J}=16.6,10.1,6.3 \mathrm{~Hz}, 1 \mathrm{H}), 5.50-5.34(\mathrm{~m}, 2 \mathrm{H}), 5.08(\mathrm{~d}, \mathrm{~J}=6.3 \mathrm{~Hz}, 2 \mathrm{H}) ;{ }^{13} \mathrm{C} \mathrm{NMR}$ $\left(101 \mathrm{MHz} \mathrm{CDCl}_{3}\right) \delta 185.1,148.0,130.2,125.2,121.5,53.1$. NMR data was in accordance with the previously reported data for this compound [24]. 
1-(Prop-2-yn-1-yl)-1H-1,2,3-triazole-4-carbaldehyde (7e). Prepared according to the general procedure for the synthesis of 1-alkyl-1H-1,2,3-triazole-4-carbaldehydes; propargylamine $(0.55 \mathrm{mmol}, 30 \mathrm{mg}), 1,4$-dioxane as the reaction solvent, $70{ }^{\circ} \mathrm{C}, 18 \mathrm{~h}$. Purified via column chromatography using DCM as the eluent to remove 4-nitroaniline, followed by a DCM/EtOAc gradient (9:1-4:1). Clear oil with yellowish hue; yield: $44 \mathrm{mg}$ $(65 \%) ;{ }^{1} \mathrm{H} \mathrm{NMR}\left(400 \mathrm{MHz}, \mathrm{CDCl}_{3}\right) \delta 10.15$ (s, 1H), $8.39(\mathrm{~s}, 1 \mathrm{H}), 5.28(\mathrm{~d}, J=2.6 \mathrm{~Hz}, 2 \mathrm{H})$, $2.69(\mathrm{t}, J=2.6 \mathrm{~Hz}, 1 \mathrm{H}) ;{ }^{13} \mathrm{C}$ NMR $\left(101 \mathrm{MHz}, \mathrm{CDCl}_{3}\right) \delta 184.9,147.9,125.3,77.1,74.1,40.4$; HRMS (ESI-Q-TOF): $\mathrm{m} / \mathrm{z}[\mathrm{M}+\mathrm{H}]^{+}$calcd for $\mathrm{C}_{6} \mathrm{H}_{5} \mathrm{~N}_{3} \mathrm{O}$ : 136.0505; found: 136.0512 .

1-(2,2-Dimethoxyethyl)-1H-1,2,3-triazole-4-carbaldehyde (7f). Prepared according to the general procedure for the synthesis of 1-alkyl-1H-1,2,3-triazole-4-carbaldehydes; aminoacetaldehyde dimethyl acetal $(0.55 \mathrm{mmol}, 58 \mathrm{mg}), i \mathrm{PrOH}$ as the reaction solvent. Purified via column chromatography using DCM as the eluent to remove 4-nitroaniline, followed by a DCM/EtOAc gradient (1:0-4:1). Clear oil with yellowish hue; yield: $86 \mathrm{mg}(93 \%) ;{ }^{1} \mathrm{H} \mathrm{NMR}\left(300 \mathrm{MHz}, \mathrm{CDCl}_{3}\right) \delta 10.14(\mathrm{~s}, 1 \mathrm{H}), 8.28(\mathrm{~s}, 1 \mathrm{H}), 4.75-4.65(\mathrm{~m}, 1 \mathrm{H})$, $4.57(\mathrm{~d}, J=5.0 \mathrm{~Hz}, 2 \mathrm{H}), 3.44$ (s, 6H); ${ }^{13} \mathrm{C} \mathrm{NMR}\left(151 \mathrm{MHz}, \mathrm{CDCl}_{3}\right) \delta 184.9,147.7,126.8,102.0$, $55.1,52.0$.

tert-Butyl 2-(4-formyl-1H-1,2,3-triazol-1-yl)acetate (7g). Prepared according to the general procedure for the synthesis of 1-alkyl-1H-1,2,3-triazole-4-carbaldehydes; tert-butyl glycinate $(0.55 \mathrm{mmol}, 72 \mathrm{mg}), 1 \mathrm{~mL}$ iPrOH or 1,4-dioxane as the reaction solvent. Purified via column chromatography using DCM as the eluent to remove 4-nitroaniline, followed by a DCM/EtOAc gradient (9:1-4:1). Off-white crystalline solid; yield: $43 \mathrm{mg}$ (41\%) and $47 \mathrm{mg}(45 \%)$ for reactions in $i \mathrm{PrOH}$ and dioxane, resp.; $\mathrm{mp} 93-95{ }^{\circ} \mathrm{C}$; ${ }^{1} \mathrm{H} \mathrm{NMR}$ $\left(400 \mathrm{MHz} \mathrm{CDCl}_{3}\right) \delta 10.15(\mathrm{~s}, 1 \mathrm{H}), 8.30(\mathrm{~s}, 1 \mathrm{H}), 5.17(\mathrm{~s}, 2 \mathrm{H}), 1.50(\mathrm{~s}, 9 \mathrm{H}) ;{ }^{13} \mathrm{C} \mathrm{NMR}(101 \mathrm{MHz}$, $\left.\mathrm{CDCl}_{3}\right) \delta 184.9,164.6,148.0,127.0,84.6,51.7,28.0$. NMR data was in accordance with the previously reported data for this compound [28].

1,1', $\mathbf{1}^{\prime \prime}$-(Nitrilotris(ethane-2,1-diyl))tris(1H-1,2,3-triazole-4-carbaldehyde) (7h). FNPT 1a $(0.83 \mathrm{mmol}, 180 \mathrm{mg})$, tris(2-aminoethyl)amine $(0.25 \mathrm{mmol}, 36.5 \mathrm{mg}), i \mathrm{PrOH}(0.5 \mathrm{~mL})$ and water $(1.5 \mathrm{~mL})$ were added in this sequence to a screw-capped reaction tube equipped with a magnetic stirring bar. The reaction mixture was stirred for $17 \mathrm{~h}$ at $80{ }^{\circ} \mathrm{C}$. Next, the aqueous solution was extracted with DCM $(2 \times 10 \mathrm{~mL})$ after which the combined organic layers were dried over $\mathrm{Na}_{2} \mathrm{SO}_{4}$, filtered, and concentrated. The crude product was further purified via column chromatography using a DCM/EtOAc gradient (1:0-3:2) as the eluent to remove 4-nitroaniline and the starting triazole 1a, followed by a DCM/MeOH gradient (49:1-19:1). Off-white solid; yield: $87 \mathrm{mg}(90 \%) ; \mathrm{mp} 146-151{ }^{\circ} \mathrm{C} ;{ }^{1} \mathrm{H} \mathrm{NMR}(400 \mathrm{MHz}$, DMSO- $\left.d_{6}\right) \delta 9.96(\mathrm{~s}, 3 \mathrm{H}), 8.54(\mathrm{~s}, 3 \mathrm{H}), 4.44(\mathrm{t}, J=6.2 \mathrm{~Hz}, 6 \mathrm{H}), 3.06(\mathrm{t}, J=6.3 \mathrm{~Hz}, 6 \mathrm{H}) ;{ }^{13} \mathrm{C}$ NMR (101 MHz, DMSO) $\delta$ 184.9, 146.7, 128.0, 52.0, 47.4; HRMS (ESI-Q-TOF): m/z [M + H] ${ }^{+}$ calcd for $\mathrm{C}_{15} \mathrm{H}_{18} \mathrm{~N}_{10} \mathrm{O}_{3}$ : 387.1636; found: 387.1633 .

Supplementary Materials: The following are available online at https: / www.mdpi.com/article / 10.3390/org2040024/s1, NMR spectra of isolated compounds and Figure S1: ${ }^{1} \mathrm{H}$ NMR spectra in DMSO- $d_{6}(300 \mathrm{MHz})$ of 1-(4-nitrophenyl)-1H-1,2,3-triazole-4-carbaldehyde 1a (collected via filtration) before drying under vacuo.

Author Contributions: Conceptualization, T.O. and W.D.; experimental investigation, T.O., K.V. and A.R.; formal analysis, T.O., K.V. and A.R.; writing-original draft preparation, T.O.; writingreview and editing, T.O. and W.D.; supervision, T.O. and W.D.; project administration, W.D.; funding acquisition, W.D. All authors have read and agreed to the published version of the manuscript.

Funding: This research was funded by KU Leuven (C14/19/78 and PDM/20/091) and the Fonds Wetenschappelijk Onderzoek (1154419N).

Institutional Review Board Statement: Not applicable.

Informed Consent Statement: Not applicable.

Data Availability Statement: Not applicable.

Acknowledgments: The authors thank Sergio Ribone for his help with the initial experiments and Bart Van Huffel for his assistance with the NMR measurements. T.O. acknowledges the 
FWO-Vlaanderen for a PhD fellowship (1154419N) and KU Leuven for a postdoctoral mandate (PDM/20/091). W.D. acknowledges financial support from KU Leuven (Project C14/19/78). Mass spectrometry was made possible by the support of the Hercules Foundation of the Flemish Government (grant 20100225-7).

Conflicts of Interest: The authors declare no conflict of interest.

\section{References}

1. Onoda, A.; Inoue, N.; Sumiyoshi, E.; Hayashi, T. Triazolecarbaldehyde Reagents for One-Step N-Terminal Protein Modification. ChemBioChem 2020, 21, 1274-1278. [CrossRef] [PubMed]

2. Bagdi, P.R.; Basha, R.S.; Khan, A.T. Synthesis of 2-triazolyl-imidazo[1,2-a]pyridine through a one-pot three-component reaction using a nano copper oxide assisted click-catalyst. RSC Adv. 2015, 5, 61337-61344. [CrossRef]

3. Lee, I.; Choe, Y.S.; Choi, J.Y.; Lee, K.-H.; Kim, B.-T. Synthesis and Evaluation of 18F-Labeled Styryltriazole and Resveratrol Derivatives for $\beta$-Amyloid Plaque Imaging. J. Med. Chem. 2012, 55, 883-892. [CrossRef] [PubMed]

4. Sambasiva Rao, P.; Ashalu, K.C.; Dev, G.J.; Ravi Kumar, N.; Srinivas, P.V.S.S.; Thomas, B.V.; Narsaiah, B. Efficient method for the synthesis of 1,2,3-triazole functionalized isoxazolidine derivatives by 1,3-dipolar cycloaddition of nitrones with terminal olefins. Synth. Commun. 2017, 47, 457-462. [CrossRef]

5. Chan, T.R.; Fokin, V.V. Polymer-Supported Copper(I) Catalysts for the Experimentally Simplified Azide-Alkyne Cycloaddition. QSAR Comb. Sci. 2007, 26, 1274-1279. [CrossRef]

6. Sallustrau, A.; Bregant, S.; Chollet, C.; Audisio, D.; Taran, F. Scalable and practical synthesis of clickable Cu-chelating azides. Chem. Commun. 2017, 53, 7890-7893. [CrossRef]

7. Da SM Forezi, L.; Lima, C.G.; Amaral, A.A.; Ferreira, P.G.; de Souza, M.C.B.; Cunha, A.C.; Ferreira, V.F. Bioactive 1,2,3-Triazoles: An Account on their Synthesis, Structural Diversity and Biological Applications. Chem. Rec. 2021, 21, 2782-2807. [CrossRef]

8. Zhao, J.-W.; Guo, J.-W.; Huang, M.-J.; You, Y.-Z.; Wu, Z.-H.; Liu, H.-M.; Huang, L.-H. Design, synthesis and biological evaluation of new steroidal $\beta$-triazoly enones as potent antiproliferative agents. Steroids 2019, 150, 108431. [CrossRef] [PubMed]

9. Sambasiva Rao, P.; Kurumurthy, C.; Veeraswamy, B.; Santhosh Kumar, G.; Shanthan Rao, P.; Pamanji, R.; Venkateswara Rao, J.; Narsaiah, B. Synthesis of novel 2-alkyl triazole-3-alkyl substituted quinoline derivatives and their cytotoxic activity. Bioorg. Med. Chem. Lett. 2013, 23, 1225-1227. [CrossRef] [PubMed]

10. Sambasiva Rao, P.; Kurumurthy, C.; Veeraswamy, B.; Santhosh Kumar, G.; Poornachandra, Y.; Ganesh Kumar, C.; Vasamsetti, S.B.; Kotamraju, S.; Narsaiah, B. Synthesis of novel 1,2,3-triazole substituted-N-alkyl/aryl nitrone derivatives, their anti-inflammatory and anticancer activity. Eur. J. Med. Chem. 2014, 80, 184-191. [CrossRef] [PubMed]

11. Dai, Z.-C.; Chen, Y.-F.; Zhang, M.; Li, S.-K.; Yang, T.-T.; Shen, L.; Wang, J.-X.; Qian, S.-S.; Zhu, H.-L.; Ye, Y.-H. Synthesis and antifungal activity of 1,2,3-triazole phenylhydrazone derivatives. Org. Biomol. Chem. 2015, 13, 477-486. [CrossRef] [PubMed]

12. Wang, X.; Dai, Z.-C.; Chen, Y.-F.; Cao, L.-L.; Yan, W.; Li, S.-K.; Wang, J.-X.; Zhang, Z.-G.; Ye, Y.-H. Synthesis of 1,2,3-triazole hydrazide derivatives exhibiting anti-phytopathogenic activity. Eur. J. Med. Chem. 2017, 126, 171-182. [CrossRef] [PubMed]

13. Boechat, N.; Ferreira, V.F.; Ferreira, S.B.; Ferreira, M.D.L.G.; da Silva, F.D.C.; Bastos, M.M.; Costa, C.C. Novel 1,2,3-Triazole Derivatives for Use against Mycobacterium tuberculosis H37Rv (ATCC 27294) Strain. J. Med. Chem. 2011, 54, 5988-5999. [CrossRef] [PubMed]

14. Costa, M.S.; Boechat, N.; Rangel, E.A.; Da Silva, F.D.C.; De Souza, A.M.; Rodrigues, C.R.; Ferreira, V.F. Synthesis, tuberculosis inhibitory activity, and SAR study of N-substituted-phenyl-1,2,3-triazole derivatives. Bioorg. Med. Chem. 2006, 14, 8644-8653. [CrossRef] [PubMed]

15. Goud, G.L.; Ramesh, S.; Ashok, D.; Reddy, V.P.; Yogeeswari, P.; Sriram, D.; Saikrishna, B.; Manga, V. Design, synthesis, moleculardocking and antimycobacterial evaluation of some novel 1,2,3-triazolyl xanthenones. MedChemComm 2017, 8, 559-570. [CrossRef] [PubMed]

16. Gannarapu, M.R.; Vasamsetti, S.B.; Punna, N.; Kotamraju, S.; Banda, N. Synthesis of novel 1-substituted triazole linked 1,2benzothiazine 1,1-dioxido propenone derivatives as potent anti-inflammatory agents and inhibitors of monocyte-to-macrophage differentiation. MedChem Comm 2015, 6, 1494-1500. [CrossRef]

17. Gonzaga, D.; Senger, M.R.; Da Silva, F.D.C.; Ferreira, V.F.; Silva, F.P. 1-Phenyl-1H- and 2-phenyl-2H-1,2,3-triazol derivatives: Design, synthesis and inhibitory effect on alpha-glycosidases. Eur. J. Med. Chem. 2014, 74, 461-476. [CrossRef]

18. Pisal, M.M.; Annadate, R.A.; Athalye, M.C.; Kumar, D.; Chavan, S.P.; Sarkar, D.; Borate, H.B. Synthesis and cell imaging applications of fluorescent mono/di/tri-heterocyclyl-2,6-dicyanoanilines. Bioorg. Med. Chem. Lett. 2017, 27, 979-988. [CrossRef]

19. Hagiwara, H.; Minoura, R.; Okada, S.; Sunatsuki, Y. Synthesis, Structure, and Magnetic Property of a New Mononuclear Iron(II) Spin Crossover Complex with a Tripodal Ligand Containing Three 1,2,3-Triazole Groups. Chem. Lett. 2014, 43, 950-952. [CrossRef]

20. Hagiwara, H.; Okada, S. A polymorphism-dependent $\mathrm{T}_{1 / 2}$ shift of $100 \mathrm{~K}$ in a hysteretic spin-crossover complex related to differences in intermolecular weak $\mathrm{CH} \cdots X$ hydrogen bonds ( $\mathrm{X}=\mathrm{S}$ vs. S and N). Chem. Commun. 2016, 52, 815-818. [CrossRef] [PubMed]

21. Hagiwara, H.; Tanaka, T.; Hora, S. Synthesis, structure, and spin crossover above room temperature of a mononuclear and related dinuclear double helicate iron(ii) complexes. Dalton Trans. 2016, 45, 17132-17140. [CrossRef] 
22. Khare, S.P.; Deshmukh, T.R.; Sangshetti, J.N.; Krishna, V.S.; Sriram, D.; Khedkar, V.M.; Shingate, B.B. Design, Synthesis and Molecular Docking Studies of Novel Triazole-Chromene Conjugates as Antitubercular, Antioxidant and Antifungal Agents. ChemistrySelect 2018, 3, 13113-13122. [CrossRef]

23. Farooq, T.; Sydnes, L.K.; Törnroos, K.W.; Haug, B.E. Debenzylation of Functionalized 4- and 5-Substituted 1,2,3-Triazoles. Synthesis 2012, 44, 2070-2078. [CrossRef]

24. Fletcher, J.T.; Christensen, J.A.; Villa, E.M. Tandem synthesis of 1-formyl-1,2,3-triazoles. Tetrahedron Lett. 2017, 58, 4450-4454. [CrossRef] [PubMed]

25. Sarmiento-Sanchez, J.I.; Ochoa-Teran, A.; Rivero, I.A.; Sarmiento-Sánchez, J.I.; Ochoa-Terán, A.; Rivero, I.A. Conventional and microwave assisted synthesis of 1,4-disubstituted 1,2,3-triazoles from Huisgen cycloaddition. Arkivoc 2011, 9, 177-188. [CrossRef]

26. Janreddy, D.; Kavala, V.; Kuo, C.-W.; Chen, W.-C.; Ramesh, C.; Kotipalli, T.; Kuo, T.-S.; Chen, M.-L.; He, C.-H.; Yao, C.-F. Copper(I)-Catalyzed Aerobic Oxidative Azide-Alkene Cyclo-addition: An Efficient Synthesis of Substituted 1,2,3-Triazoles. Adv. Synth. Catal. 2013, 355, 2918-2927. [CrossRef]

27. Li, W.; Zhou, X.; Luan, Y.; Wang, J. Direct access to 1,4-disubstituted 1,2,3-triazoles through organocatalytic 1,3-dipolar cycloaddition reaction of $\alpha, \beta$-unsaturated esters with azides. RSC Adv. 2015, 5, 88816-88820. [CrossRef]

28. Zhang, D.; Fan, Y.; Yan, Z.; Nie, Y.; Xiong, X.; Gao, L. Reactions of $\alpha$-haloacroleins with azides: Highly regioselective synthesis of formyl triazoles. Green Chem. 2019, 21, 4211-4216. [CrossRef]

29. L'Abbé, G.; Vandendriessche, A. Ring-degenerate rearrangement of 5-amino-4-iminomethyl-1,2,3-triazoles. J. Heterocycl. Chem. 1989, 26, 701-703. [CrossRef]

30. Li, J.J. (Ed.) Cornforth rearrangement. In Name Reactions: A Collection of Detailed Reaction Mechanisms; Springer: Berlin/Heidelberg, Germany, 2003; p. 95. ISBN 978-3-662-05336-2.

31. Pulikkal Veettil, S.; Pookkandam Parambil, S.; Van Hoof, M.; Dehaen, W. A Multicomponent Approach toward Angularly Fused/Linear Bitriazoles: A Cascade Cornforth Rearrangement and Triazolization. J. Org. Chem. 2021, 86, 4346-4354. [CrossRef]

32. L'abbé, G.; Bruynseels, M. Replacement of aryl by alkyl in 1-substituted 1H-1,2,3-triazole-4-carbaldehydes. J. Chem. Soc. Perkin Trans. 1990, 1, 1492-1493. [CrossRef]

33. L'abbé, G.; Bruynseels, M.; Delbeke, P.; Toppet, S. Molecular rearrangements of 4-iminomethyl-1,2,3-triazoles. Replacement of 1-aryl substituents in 1H-1,2,3-triazole-4-carbaldehydes. J. Heterocycl. Chem. 1990, 27, 2021-2027. [CrossRef]

34. Fletcher, J.T.; Hanson, M.D.; Christensen, J.A.; Villa, E.M. Revisiting ring-degenerate rearrangements of 1-substituted-4-imino1,2,3-triazoles. Beilstein J. Org. Chem. 2018, 14, 2098-2105. [CrossRef]

35. Arnold, Z.; Šauliová, J. Synthetic reactions of dimethylformamide. XXVIII. Diazomalonaldehyde. Collect. Czechoslov. Chem. Commun. 1973, 38, 2641-2647. [CrossRef]

36. John, J.; Thomas, J.; Dehaen, W. Organocatalytic routes toward substituted 1,2,3-triazoles. Chem. Commun. 2015, 51, 10797-10806. [CrossRef]

37. Opsomer, T.; Dehaen, W. Metal-free syntheses of N-functionalized and NH-1,2,3-triazoles: An update on recent developments. Chem. Commun. 2021, 57, 1568-1590. [CrossRef] [PubMed]

38. Prakash, R.; Opsomer, T.; Dehaen, W. Triazolization of Enolizable Ketones with Primary Amines: A General Strategy toward Multifunctional 1,2,3-Triazoles. Chem. Rec. 2021, 21, 376-385. [CrossRef]

39. Kučera, J.; Janoušek, Z.; Arnold, Z. Synthesis of $\alpha$-diazoaldehydes. Collect. Czechoslov. Chem. Commun. 1970, 35, 3618-3627. [CrossRef]

40. Bakulev, V.A.; Beryozkina, T.; Thomas, J.; Dehaen, W. The Rich Chemistry Resulting from the 1,3-Dipolar Cycloaddition Reactions of Enamines and Azides. Eur. J. Org. Chem. 2018, 2018, 262-294. [CrossRef]

41. Thomas, J.; Goyvaerts, V.; Liekens, S.; Dehaen, W. Metal-Free Route for the Synthesis of 4-Acyl-1,2,3-Triazoles from Readily Available Building Blocks. Chem. Eur. J. 2016, 22, 9966-9970. [CrossRef] [PubMed]

42. L'abbé, G.; Verbeke, M.; Dehaen, W.; Toppet, S. Thermal rearrangement of 4-iminomethyl-1,2,3-thiadiazoles. J. Chem. Soc. Perkin Trans. 1993, 1, 1719-1725. [CrossRef]

43. Thomas, J.; Jana, S.; John, J.; Liekens, S.; Dehaen, W. A general metal-free route towards the synthesis of 1,2,3-triazoles from readily available primary amines and ketones. Chem. Commun. 2016, 52, 2885-2888. [CrossRef]

44. Ratković, A.; Mlakić, M.; Dehaen, W.; Opsomer, T.; Barić, D.; Škorić, I. Synthesis and photochemistry of novel 1,2,3-triazole di-heterostilbenes. An experimental and computational study. Spectrochim. Acta Part A Mol. Biomol. Spectrosc. 2021, $261,120056$. [CrossRef] [PubMed]

45. Opsomer, T.; Van Hoof, M.; D’Angelo, A.; Dehaen, W. 1,2,3-Triazole-Mediated Synthesis of 1-Methyleneisoquinolines: A Three-Step Synthesis of Papaverine and Analogues. Org. Lett. 2020, 22, 3596-3600. [CrossRef] [PubMed] 